\title{
Tulk, pankreas a metabolický syndrom - editorial
}

\author{
Jan Trna \\ Gastroenterologická ambulance Interního oddělení Nemocnice Boskovice \\ Komentáŕ k | Editorial on \\ Blaho M et al. Steatóza slinivky břišní: klinický význam. Vnitř Lék 2018; 64(10): 949-952.
}

Článek kolektivu autorů Blaho et al "Steatóza slinivky břišní: klinický význam“ publikovaný v tomto čísle časopisu Vnitřní lékařství se zabývá velmi aktuálním tématem - ukládáním tuku v pankreatu a klinickými konsekvencemi této situace. Akumulace tuku v pankreatu je situace známá již dlouhou dobu [1], nicméně její klinický význam a vztah k dalším chorobám především ze skupiny metabolického syndromu jsou intenzivněji zkoumány teprve v posledních letech. Navíc obecná povědomost o této problematice je stále relativně nízká.

Současná civilizace v tzv. rozvinutém světě se potýká s epidemií obezity [2]. Obezita prokazatelně souvisí s inzulinovou rezistencí (vedoucí k hyperglykemii a potažmo k diabetu), prokazatelná je též souvislost s dalšími chorobami tvořícími tzv. metabolický syndrom (hypertenze a dyslipidemie). Obezita též vede k endoteliální dysfunkci podmiňující rozvoj aterosklerózy [3] a vede k tukové infiltraci v řadě orgánů - svaly, srdce, ledviny, játra a pankreas [4].

Fakt, že pankreaty obézních jedinců obsahují více tuku než pankreaty jedinců štíhlých, je prokázán již relativně dlouhou dobu [5]. Nové též není ani zjištění, že obsah tuku v pankreatu narůstá s věkem a že osoby s vysokým obsahem tuku v pankreatu mají signifikantně vyšší riziko diabetu a aterosklerózy [6]. Celkově však klinický význam zvýšeného obsahu tuku v pankreatu není jednoznačný a výzkum tohoto fenoménu je jednou z dynamicky se rozvíjejících oblastí pankreatologie s přesahem do řady oblastí vnitřního lékařství.

Již samo názvosloví je problematické a lze se setkat s termíny lipomatóza, steatóza, ztukovatění pankreatu a nověji i s termíny, které kopírují obdobné jednotky jaterní - nealkoholická tuková choroba pankreatu (Non-Alcoholic Fatty Pancreas Disease - NAFPD) a nealkoholická steatopankreatitida (Non-Alcoholic SteatoPancreatitis NASP). Podobně jako u ztukovatění jater je zásadní, jestli dochází „pouze“ ke zvýšení obsahu tuku v pankreatu, nebo jestli dochází k poškození a zániku buněk pankreatu a jejich náhradě adipocyty. Nově užívaný termín NAFPD je v paralele s nealkoholickou tukovou chorobou jater (Non-Alcoholic Fatty Liver Disease - NAFLD) navrženo používat pro postižení pankreatu, které souvisí s obezitou a metabolickým syndromem [7]. Tíže postižení pak může kolísat od prostého ukládání tuku v pankreatu po zánětlivé změny vedoucí ke ztrátě funkčního parenchymu a fibrotizaci žlázy. Tato podstatně závažnější forma (někdy nazývaná steatopankreatitida) již může vést $\mathrm{k}$ poškození exokrinní i endokrinní funkce, zvýšení rizika akutní pankreatitidy (prrípadně jejímu těžšímu průběhu), a dokonce až ke zvýšení rizika rozvoje karcinomu pankreatu $[7,8]$.

V současné době přibývá důkazů, že NAFPD je v obecné populaci přítomna relativně často a úzce souvisí s metabolickým syndromem [9]. Někteři autoři proto navrhují zahrnout NAFPD mezi součásti metabolického syndromu $[10,11]$. Dle některých prací se zdá, že přítomnost NAFPD s ostatními součástmi metabolického syndromu koreluje dokonce lépe než NAFLD a řada pacientů má ultrasonograficky dřive detekovatelnou NAFPD než NAFLD [12]. Nabízí se tudíž možnost využití nálezu NAFPD v časné detekci a intervenci metabolického syndromu, nicméně situace si vyžaduje další systematický výzkum.

Závěrem Ize konstatovat, že článek kolektivu autorů Blaho et al "Steatóza slinivky břišní: klinický význam" by měl právem přitáhnout pozornost široké rodiny čtenářù časopisu Vnitřní lékařství k této zajímavé a dosud nepř́liš probádané oblasti, která se zdaleka netýká jen pankreatologie.

\section{Literatura}

1. Schaefer $\mathrm{JH}$. The normal weight of the pancreas in the adult human being: A biometric study. Anat Rec 1926; 32: 119-132. Dostupné z DOI: <https://doi.org/10.1002/ar.1090320204>.

2. Ogden $C L$, Carroll MD, Kit BK et al. Prevalence of childhood and adult obesity in the United States, 2011- 2012. JAMA 2014; 311(8): 806814. Dostupné z DOI: <http://dx.doi.org/10.1001/jama.2014.732>.

3. Lindsay RS, Howard BV. Cardiovascular risk associated with the metabolic syndrome. Curr Diab Rep 2004; 4(1): 63-68.

4. Lim S, Meigs JB. Ectopic fat and cardiometabolic and vascular risk. Int J Cardiol 2013; 169(3): 166-176. Dostupné z DOI: <http://dx.doi.org/10.1016/j.ijcard.2013.08.077>.

5. Olsen TS. Lipomatosis of the pancreas in autopsy material and its relation to age and overweight. Acta Pathol Microbiol Scand A 1978; 86A(5): 367-373.

6. Stamm BH. Incidence and diagnostic significance of minor pathologic changes in the adult pancreas at autopsy: a systematic study of 112 autopsies in patients without known pancreatic disease. Hum Pathol 1984; 15(7): 677- 683.

7. Smits MM, van Geenen EJ. The clinical significance of pancreatic steatosis. Nat Rev Gastroenterol Hepatol 2011; 8(3): 169-177. Dostupné z DOI: <http://dx.doi.org/10.1038/nrgastro.2011.4>. 
8. Tomita $Y$, Azuma $K$, Nonaka $Y$ et al. Pancreatic fatty degeneration and fibrosis as predisposing factors for the development of pancreatic ductal adenocarcinoma. Pancreas 2014; 43(7): 1032-1041. Dostupné z DOl: <http://dx.doi.org/10.1097/MPA.0000000000000159>.

9. Singh RG, Yoon HD, Wu LM et al. Ectopic fat accumulation in the pancreas and its clinical relevance: A systematic review, meta-analysis, and meta-regression. Metabolism 2017; 69: 1-13. Dostupné z DOI: <http://dx.doi.org/10.1016/j.metabol.2016.12.012>.

10. Wu WC, Wang CY. Association between non-alcoholic fatty pancreatic disease (NAFPD) and the metabolic syndrome: case-control retrospective study. Cardiovasc Diabetol 2013; 12: 77. Dostupné z DOI: <http://dx.doi.org/10.1186/1475-2840-12-77>.

11. Romana B, Chela H, Dailey F et al. Non-alcoholic fatty pancreas disease (NAFPD): A silent spectator or the fifth component of metabolic syndrome? A literature review. Endocr Metab Immune Disord Drug
Targets 2018; 18(6): 547-554. Dostupné z DOI: <http://dx.doi.org/10.21 74/1871530318666180328111302>.

12. Li S, Su L, Lv G et al. Transabdominal ultrasonography of the pancreas is superior to that of the liver for detection of ectopic fat deposits resulting from metabolic syndrome. Medicine (Baltimore) 2017; 96(37): e8060. Dostupné z DOI: <http://dx.doi.org/10.1097/ MD.0000000000008060>.

\section{MUDr. Jan Trna, Ph.D.}

凶jan.trna@seznam.cz

Gastroenterologická ambulance Interního oddělení Nemocnice Boskovice

www.nembce.cz

Doručeno do redakce 28. 6. 2018 